\title{
Evaluasi Aspek Teknis Pemeliharaan Kambing Peranakan Etawa (PE) Menuju Good Dairy Farming Practice (GDFP) di PT. Boncah Utama Kabupaten Tanah Datar
}

\section{Evaluation of Technical Aspects of Maintenance Etawa Crossbred Dairy Goat Towards Good Dairy Farming Practice (GDFP) at PT. Boncah Utama, Tanah Datar District}

\author{
Arief $^{1)^{*}}$, Elly Roza ${ }^{1)}$, dan Bonica Oktaviona ${ }^{2)}$ \\ 1) Bagian Teknologi Produksi Ternak, Fakultas Peternakan Universitas Andalas, Padang, West Sumatera \\ 2) Mahasiswa Program Pascasarjana, Fakultas Peternakan, Universitas Andalas, Padang, West Sumatera \\ Email: aarief@ansci.unand.ac.id
}

\author{
Diterima : o9 November 2020 \\ Disetujui : 26 Februari 2021 \\ Diterbitkan : 28 Februari 2021
}

\begin{abstract}
Abstrak: Penelitian ini bertujuan untuk mengevaluasi aspek teknis pemeliharaan kambing Peranakan Etawa (PE) berdasarkan panduan Good Dairy Farming Practice (GDFP) di PT. Boncah Utama Kabupaten Tanah Datar. Metode yang digunakan adalah survey dan observasi langsung di Usaha Peternakan kambing PE PT Boncah Utama dan analisis laboratorium. Sebanyak 15 ekor kambing PE diberi perlakuan dengan menerapkan Good Milking Practices (GMiP). Jenis data yang digunakan adalah data primer dan data sekunder. Analisis data dilakukan secara deskriptif. Peubah yang diamati adalah total plate count dan evaluasi aspek teknis pemeliharaan menggunakan kuisioner yang berpedoman pada pelaksanaan GDFP modifikasi dari metode FAO/IDF (2010) dan penghitungan kandungan total bakteri susu (Total Plate Count). Hasil penelitian menunjukkan bahwa penerapan GDFP di Peternakan Kambing PE PT Boncah Utama Kabupaten Tanah Datar sudah cukup baik dan analisis keragaman terhadap TPC menunjukkan bahwa perlakuan berpengaruh nyata terhadap total plate count susu (P<0.05). Kesimpulan penelitian ini adalah evaluasi GDFP di PT Bocah Utama sudah cukup baik dan sangat penting diterapkan untuk memastikan susu yang dihasilkan berkualitas dan memenuhi standar yang sudah ditetapkan.
\end{abstract}

Kata Kunci : evaluasi GDFP, total plate count, kambing PE

Abstract: The aims of present study was to evaluate of technical aspects of crossbreed etawa goat (PE) based on the guide Good Dairy Farming Practice (GDFP) at PT. Boncah Utama, Tanah Datar Regency. The study used all PE goats. 15 of PE were treated by applying Good Milking Practices (GMiP). The methods used were survey, observation and laboratory analysis. The types of data used were primary data and secondary data. The data analysis was carried out descriptively. The variables observed were total plate count and evaluation of technical aspects of maintenance using a questionaire guided by the implementation of the modified GDFP from the FAO/IDF method (2010). The results of the analysis of diversity showed that the treatment had a significant effect $(P<0.05)$ on total plate count of milk. The conclusion of this study that the evaluation of GDFP is very important to ensure quality milk produced and the application of GMiP can be carried out hence the total milk bacteria meet the predetermined standards.

Keywords : GDFP evaluation, total plate count, etawa crossbreed dairy goat

\section{Pendahuluan}

Peternakan kambing perah merupakan salah satu usaha yang menghasilkan nilai fungsional sebagai kambing penghasil susu dan daging. Keunggulan ternak kambing yaitu pemeliharaannya tidak membutuhkan lahan yang luas, tenaga kerja sedikit, adaptif terhadap lingkungan dan pakan, dewasa tubuh dan kelamin cepat, jumlah anak per kelahiran lebih dari satu, kidding interval yang pendek serta masa kebuntingan yang relatif cepat. Salah satu sentra usaha peternakan kambing Peranakan Etawa (PE) di Sumatera Barat adalah PT. Boncah Utama yang berlokasi di Kenagarian Barulak, 
Kecamatan Tanjung Baru, Kabupaten Tanah Datar. Topografi daerahnya perbukitan dengan rata-rata ketinggian 750-1000 $\mathrm{m}$ di atas permukaan laut, suhu udaranya berkisar antara $21^{\circ} \mathrm{C}-27^{\circ} \mathrm{C}$ dengan kelembaban udara antara $60-80 \%$ daerah ini baik untuk usaha ternak kambing.

Peningkatan kualitas susu di PT. Bocah Utama dapat dilakukan dengan perbaikan teknis atau manajemen pemeliharaan ternak. Kualitas susu ternak dapat dilihat dari dua aspek yaitu segi kualitas dan kuantitas. Mulai dari aspek pemuliaan dan reproduksi, manajemen pakan dan air minum, kandang dan peralatan, aspek pemerahan, lingkungan dan kesehatan ternak. Penerapan aspek teknis dengan memperhatikan dan mempertimbangkan tata kelola yang baik akan meningkatkan efisiensi usaha ternak perah. Untuk mewujudkan hal tersebut diperlukan pedoman budidaya ternak kambing perah yang baik (Good Dairy Farming Practice). Good Dairy Farming Practice merupakan cara beternak yang baik dan benar.

Aspek teknis pemeliharaan dapat mempengaruhi kualitas susu yang dihasilkan terutama aspek pemberian pakan sebagai sumber energi dan nutrisi yang dibutuhkan untuk memproduksi susu yang berkualitas. Oleh karena itu, evaluasi aspek teknis pemeliharaan terhadap kambing PE perlu dilakukan. Selain itu, identifikasi faktor-faktor yang berpengaruh terhadap kualitas susu kambing PE penting untuk dirumuskan. Penelitian ini dilakukan untuk mengevaluasi penerapan Good Dairy Farming Practice (GDFP) kambing PE di PT. Boncah Utama Kenagarian Barulak Kabupaten Tanah Datar. Untuk menuju GDFP di PT. Boncah Utama maka perlu dilakukan penerapan sanitasi pemerahan.

\section{Materi dan Metode}

Penelitian ini menggunakan seluruh ternak kambing PE di PT. Boncah Utama sebagai sampel dan susu kambing segar hasil pemerahan pagi hari dalam bentuk susu kandang untuk analisis total plate count. Peralatan yang digunakan dalam penelitian ini untuk analisis proksimat adalah seperangkat alat sochlet, seperangkat alat destilasi, oven listrik, cawan porselen, desikator, timbangan analitik, pipet tetes, kertas saring, labu Kjeldhal, erlenmeyer, hotplate. Pengujian total plate count pada susu diperlukan peralatan berupa cawan petri, coolbox, milkcan, laktoscan, alat tulis dan alat dokumentasi.

\subsection{Rancangan Percobaan}

Metode penelitian ini adalah metode survei dan pengamatan langsung di lapangan terhadap usaha peternakan kambing PE di PT. Boncah Utama. 15 ekor kambing PE diberi perlakuan dengan menerapkan Good Milking Practices (GMiP). Jenis data yang digunakan adalah data primer dan data sekunder. Data primer yaitu data yang diperoleh langsung pada saat melakukan kegiatan di lapangan dan juga melalui wawancara yang berpedoman pada lembar kuisioner dan evaluasi penerapan GDFP. Data sekunder yaitu data diperoleh dari pencatatan selama penelitian, studi literatur, instansi terkait dan hasil penelitian yang relevan dengan masalah penelitian.

\subsection{Pelaksanaan Penelitian}

Prosedur dalam penelitian ini adalah melakukan observasi/pengamatan dan wawancara langsung serta menggunakan kuisioner. Menerapkan sanitasi pemerahan yaitu sebelum pemerahan dilakukan sanitasi terhadap ternak, sanitasi terhadap pemerah dan kandang, ambing dan bagian sekitar ambing dibersihkan menggunakan handuk dengan air hangat lalu puting diberi vaselin, selanjutnya proses pemerahan dapat dilakukan. Setelah pemerahan, dilakukan celup puting (teat dipping) untuk mencegah penularan penyakit.

Penilaian aspek teknis berdasarkan pada pedoman pelaksanaan GDFP modifikasi dari metode [1]. Setelah sampel susu didapatkan, sampel dimasukkan kedalam coolbox kemudian dibawa ke Laboratorium Kesehatan Masyarakat Veteriner (Kesmavet, Balai Veteriner Bukittinggi untuk analisis koloni bakteri susu (total plate count) susu. Analisa proksimat pakan dilakukan di Laboratorium Nutrisi Non Ruminansia Fakultas Peternakan Universitas Andalas. Selanjutnya dilakukan analisis data secara deskriptif.

\subsection{Peubah yang Diamati}

Pada penelitian ini peubah yang diamati adalah evaluasi penerapan GDFP meliputi aspek pembibitan dan reproduksi, manajemen pakan dan air minum, tatalaksana pemeliharan (pengelolaan), kandang dan peralatan serta kesehatan ternak menggunakan kuesioner Good Dairy farming Practice (GDFP).

\subsection{Analisa Data}

Data yang didapatkan diolah menggunakan ratarata dan standar deviasi (Sd). Data dikonversikan sesuai poin-poin yang telah disusun dan diberi skor 4 , 3, 2, 1 dan o pada setiap alternatif jawaban (Tabel 1). Nilai yang didapat dari setiap aspek teknis kemudian dirata-ratakan. 
Tabel 1. Nilai konversi performa ternak sesuai pedoman GDFP

\begin{tabular}{ccc}
\hline Nilai Rataan GDFP & Nilai Mutu & Keterangan \\
\hline $0.00-0.50$ & 0 & Sangat buruk \\
$0.51-1.00$ & 1 & Buruk \\
$1.01-2.00$ & 2 & Kurang baik \\
$2.01-3.00$ & 3 & Cukup baik \\
$3.01-4.00$ & 4 & Baik \\
\hline
\end{tabular}

Tabel 2. Komposisi dan kandungan nutrisi pakan kambing PE di PT. Boncah Utama Kabupaten Tanah Datar

\begin{tabular}{lcccccc}
\hline \multirow{2}{*}{$\begin{array}{c}\text { Sampel } \\
\text { (Hijauan) }\end{array}$} & \multirow{2}{*}{ Air (\%) } & $\begin{array}{c}\text { Bahan } \\
\text { Kering (\%) }\end{array}$ & Protein Kasar & Lemak Kasar & Serat Kasar & Abu \\
\hline Gamal & 78,97 & 21,03 & 17,61 & 5,01 & 15,37 & 6,20 \\
Indigofera & 80,92 & 19,08 & 18,02 & 4,29 & 17,63 & 8,53 \\
Daun Ubi Jalar & 86,81 & 13,19 & 14,35 & 3,38 & 16,94 & 13,50 \\
Titonia & 81,79 & 18,21 & 16,45 & 3,84 & 1,52 & 8,92 \\
Odot & 81,41 & 18,58 & 5,91 & 3,41 & 23,02 & 7,59 \\
Konsentrat & 10.62 & 89.38 & 16.64 & 7.28 & 15.96 & 5.18 \\
\hline
\end{tabular}

Sumber : Hasil Analisa Proksimat di Laboratorium Nutrisi Non Ruminansia, Fakultas Peternakan Universitas Andalas, 2019

\section{Hasil dan Pembahasan}

\subsection{Evaluasi Penerapan Good Dairy Farming Practice (GDFP)}

Pencapaian aspek manajemen peternakan sapi perah yang baik (GDFP) pada peternakan kambing perah dapat dilihat dari pengetahuan dan keterampilan teknis beternak kambing perah di PT. Boncah Utama. Berdasarkan hasil pengamatan nilai GDFP pada peternakan PT. Boncah Utama, penerapan GDFP di Peternakan kambing PE Boncah Utama termasuk dalam kategori baik dengan nilai rataan $3.52($ Tabel 3$)$.

Tabel 3. Nilai Good Dairy Farming Practice kambing perah di PT. Boncah Utama

\begin{tabular}{clcc}
\hline No & \multicolumn{1}{c}{ Faktor Penentu } & Nilai GDFP & Kategori GDFP \\
\hline 1 & Aspek Bibit dan Reproduksi & 3.43 & Baik \\
2 & Manajemen Pakan dan Air Minum & 3.33 & Baik \\
3 & Pengelolaan & 3.00 & Cukup Baik \\
4 & Kandang dan Peralatan & 3.83 & Baik \\
5 & Kesehatan Ternak & 2.66 & Cukup Baik \\
& Rata-rata & 3.25 & Baik \\
\hline
\end{tabular}

\subsection{Aspek Bibit dan Reproduksi}

Pemilihan bibit unggul merupakan kegiatan yang sangat penting dalam usaha ternak kambing perah karena akan mempengaruhi keberhasilan usaha peternakan tersebut. Nilai GDFP aspek bibit dan reproduksi di PT. Boncah Utama dalam kategori baik yaitu 3.43 seperti pada Tabel 4 .

Tabel 4. Nilai Good Dairy Farming Practice usaha peternakan kambing PE PT Boncah Utama pada aspek bibit dan reproduksi

\begin{tabular}{clcc}
\hline No & \multicolumn{1}{c}{ Faktor } & Nilai GDFP & Kategori \\
\hline 1. & Bangsa kambing yang dipelihara & 4 & Baik \\
2. & Cara seleksi & 3 & Cukup Baik \\
3. & Cara pengawinan & 2 & Kurang Baik \\
4. & Pengetahuan berahi & 3 & Cukup Baik \\
5. & Umur beranak pertama kali & 4 & Baik \\
6. & Saat dikawinkan setelah beranak & 4 & Baik \\
7. & Calving Interval & 3 & Cukup Baik \\
& Rata-rata & 3.43 & Baik \\
\hline
\end{tabular}

Rataan hasil evaluasi penerapan GDFP di PT. Boncah Utama untuk aspek bibit dan reproduksi adalah 3.43 yang berarti termasuk dalam kategori baik. Hasil pengamatan di lapangan dikatahui bahwa bangsa ternak kambing perah yang dipelihara di peternakan yang diteliti adalah kambing Peranakan Etawa (PE) yang termasuk ke dalam bangsa kambing perah unggul dengan ciri memiliki warna bulu 
kombinasi putih dan hitam/ putih dan coklat, telingga panjang dan menggantung, muka cembung dengan bulu rewos/surai menggantung terkulai. Peternak di lokasi penelitian memilih bibit ternak yang sudah memasuki umur siap kawin. Tujuannya adalah agar peternak memiliki waktu untuk mengembalikan kondisi dan mengupayakan ternak tersebut beradaptasi dengan lingkungan barunya. Secara umum peternak sudah menguasai teknik pemilihan dan standard kualitas bibit kambing.

Aspek cara kawin memperoleh nilai kurang baik karena ternak kambing dikawinkan dengan cara kawin alam menggunakan pejantan unggul. Kondisi aspek pengetahuan birahi termasuk dalam kategori cukup baik dimana peternak sudah mengetahui tanda-tanda birahi pada kambing yaitu sering mengembik, gelisah, alat kelamin bagian luar bengkak, basah, merah dan diam bila dinaiki oleh pejantan.

Pada sub aspek umur beranak pertama, didapatkan bahwa umur beranak pertama kambing PE di PT. Boncah Utama adalah 17-19 bulan yang termasuk ke dalam kategori baik. Umur dikawinkan setelah beranak yaitu 6o-9o hari. Calving interval yaitu 9-11 bulan yang juga termasuk ke dalam kategori cukup baik. Calving interval dipengaruhi oleh jarak waktu kawin kembali setelah beranak, deteksi birahi dan faktor pakan. Calving interval lebih dari 8 bulan akan menyebabkan produksi susu menurun. Jarak beranak yang baik adalah 8 bulan. Umur beranak dipengaruhi oleh pencapaian dewasa kelamin, dewasa tubuh dan kandungan nutrisi pada pakan yang dikonsumsi. Umur beranak pertama yang lebih tinggi disebabkan oleh keterlambatan peternak dalam mengawinkan ternak pertama kali. [2] mengatakan tingkat deteksi estrus rendah, pemenuhan nutrisi ternak yang rendah dan kurangnya pencatatan reproduksi memberikan kontribusi buruk terhadap asspek reproduksi usaha peternakan.

\subsection{Pakan dan Air Minum}

Produksi ternak ruminansia sangat ditentukan oleh ketersediaan pakan. Jenis pakan yang diberikan untuk kambing, yaitu hijauan dan konsentrat. Kecukupan nutrisi pokok pada ternak kambing digunakan untuk pertumbuhan, reproduksi, laktasi dan gerak. Berdasarkan evaluasi penerapan GDFP untuk aspek pakan dan air minum (Tabel 5) skor rata-rata 3.33 dapat dikatakan bahwa performa peternakan termasuk kategori baik.

Tabel 5. Nilai Good Dairy Farming Practice kambing perah aspek pakan dan air minum

\begin{tabular}{clcl}
\hline No & Faktor & Nilai GDFP & Kategori \\
\hline 1. & Cara pemberian hijauan & 4 & Baik \\
2. & Jumlah pemberian hijauan & 3 & Cukup Baik \\
3. & Kualitas hijauan & 4 & Baik \\
4. & Frekuensi pemberian hijauan & 3 & Cukup Baik \\
5. & Cara pemberian konsentrat & 4 & Baik \\
6. & Jumlah pemberian konsentrat & 3 & Cukup Baik \\
7. & Kualitas konsentrat & 3 & Cukup Baik \\
8. & Frekuensi pemberian konsentrat & 2 & Kurang Baik \\
9. & Pemberian air minum & 4 & Baik \\
& Rata-rata & 3.33 & Baik \\
\hline
\end{tabular}

Sub aspek cara pemberian pakan termasuk dalam kategori baik karena pakan diberikan setelah proses pemerahan selesai, hal ini bertujuan untuk mengurangi kontaminasi pada susu. Apabila diberikan sebelum pemerahan atau pada saat pemerahan maka susu akan terkontaminasi dengan bau pakan karena sifat susu mudah menyerap bau yang ada di sekitarnya. Jumlah pemberian pakan di lokasi penelitian cukup baik yaitu $\pm 2 \mathrm{~kg} / \mathrm{ekor} / \mathrm{hari}$ hijauan dan $0.5 \mathrm{~kg} / \mathrm{ekor} / \mathrm{hari}$ konsentrat. Berdasarkan hasil analisis proksimat pakan menunjukkan bahwapakan yang digunakan di PT. Boncah Utama sudah berkualitas. Pemberian hijauan dilakukan 2 kali sehari yaitu pagi dan sore hari, sedangkan pemberian konsentrat dilakukan pada pagi hari saja dan diberikan sebelum pemerahan. Pemberian pakan harus dengan presentase yang sesuai antara hijauan dan konsentrat. Apabila kualitas hijauannya tinggi, maka presentase penggunaannya dalam ransum harus ditingkatkan, sebaliknya apabila kualitas hijauan rendah, presentase dalam ransum juga harus dikurangi dengan ketentuan serat kasar dan protein harus mencapai batas minimum [3]. Semakin tinggi nilai efisiensi pakan, berarti semakin tinggi pula tingkat pemanfaatan pakan untuk menaikan produksi ternak. Menurut [4] menyatakan bahwa nilai efisiensi pakan pada kambing berkisar antara 6,78-13,72\%. Untuk mengetahui kualitas dari bahan pakan di lokasi penelitian, maka dilakukan uji kualitas pakan.

Salah satu faktor terpenting adalah pemberian air minum. Kebutuhan air semakin meningkat pada kambing yang sedang laktasi. Air diperlukan untuk memproduksi susu yang mengandung 80\%-90\% air dalam fase laktasi. Berdasarkan hasil evaluasi GDFP sub aspek pemberian air minum secara ad libitum termasuk dalam kategori baik. 


\subsection{Tatalaksana Pemeliharaan (Pengelolaan)}

Tabel 6 menampilkan sub aspek manajemen pengelolaan yang dilakukan pada pemeliharaan kambing perah di PT. Boncah Utama. Hasil evaluasi penerapan GDFP secara umum tergolong cukup baik yaitu 3.00.

Tabel 6. Nilai Good Dairy Farming Practice kambing perah aspek pemeliharaan (pengelolaan)

\begin{tabular}{clcc}
\hline No & \multicolumn{1}{c}{ Faktor } & Nilai GDFP & Kategori \\
\hline 1. & Membersihkan kambing & 4 & Baik \\
2. & Cara membersihkan kambing & 2 & Kurang Baik \\
3. & Membersihkan kandang & 4 & Baik \\
4. & Cara pemerahan & 3 & Cukup Baik \\
5. & Penanganan pasca panen & 3 & Cukup Baik \\
6. & Pemeliharaan anak kambing dan dara & 3 & Cukup Baik \\
7. & Pengeringan kambing laktasi & 3 & Cukup Baik \\
8. & Pencatatan usaha & $\mathbf{2}$ & Kurang Baik \\
9. & Manajemen kotoran (limbah) & 3 & Cukup Baik \\
& Rata-rata & $\mathbf{3 . 0 o}$ & Cukup Baik \\
\hline
\end{tabular}

Sub aspek membersihkan/memandikan kambing dilakukan 2 kali/hari sebelum pemerahan dengan cara membersihkan ambing dan bagian sekitar ambing. Cara membersihkan kandang sudah benar yaitu sebelum melakukan pemerahan kandang terlebih dahulu kandang dibersihkan agar kotoran yang ada di sekitar kandang bersih dan mengurangi kontaminasi terhadap susu, cara yang dilakukan untuk membersikan kandang yaitu membersihkan semua bagian kandang sampai bersih. Peternak membersihkan kandang sebanyak 2 kali sehari sebelum pemerahan.

Pemerahan dilakukan 2 kali sehari yaitu pada waktu pagi dan sore hari. Pemerahan pagi hari dilakukan pada pukul o8.oo WIB dan sore hari pukul 16.oo WIB. Jarak pemerahan akan mempengaruhi produksi susu yang dihasilkan. Hal ini sejalan dengan pendapat [5] bahwa selang pemerahan yang panjang memberikan kesempatan/waktu yang relatif panjang dalam pembetukan air susu dari pakan yang dikonsumsi. Pemerahan dilakukan oleh peternak dimana sebelumnya ambing telah dibersihkan. Pada kambing yang diberi perlakuan dimana sebelum pemerahan bagian sekitar ambing dibersihkan dengan menggunakan air hangat dengan kain untuk mengurangi kontaminasi bakteri dan merangsang keluarnya susu, pemerahan dilakukan secara manual yaitu pemerahan dilakukan dengan menggunakan kelima jari tangan, yakni puting susu dipegang antara jempol dengan empat jari tangan lain, lalu kelima jari tangan meremas-remas sampai susu keluar. Susu cairan pertama (fore milk) dibuang terlebih dahulu untuk melihat susu bagus atau tidak dan membuang bakteri yang ada di saluran puting.

Berdasarkan hasil perhitungan jumlah total koloni bakteri (TPC) susu di lokasi penelitian, koloni

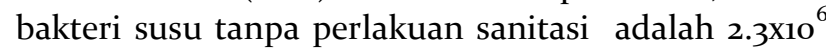
$\mathrm{CFU} / \mathrm{ml}$ sedangkan pada perlakuan sebesar $1.3 \times 10^{5}$ $\mathrm{CFU} / \mathrm{ml}$. Hasil analisis keragaman menunjukan bahwa perlakuan memberikan perbedaan yang nyata
( $\mathrm{P}<0.05)$ terhadap jumlah koloni bakteri susu susu kambing. Hal ini menunjukkan bahwa tingginya total bakteri pada kontrol dibandingkan perlakuan disebabkan oleh proses pemerahan yang belum menerapkan Good Milking Practice (GMiP). Hasil penelitian pada perlakuan telah memenuhi Standar yang ditetapkan pada SNI o1-3141-1998 susu segar yaitu sebesar $1 \mathrm{X} 10^{6}$ atau $6 \log 10 \mathrm{CFU} / \mathrm{ml}$ dan Thai Agricultural Standard [6] untuk kelas susu kambing segar standar sebesar $2 \times 10^{5}$ atau 5,30 $\log 10 \mathrm{CFU} / \mathrm{ml}$.

Proses pembersihan ambing dengan air hangat berhubungan dengan perangsangan aktifitas hormon oxytocin. Hormon oxytocin merupakan hormon yang khusus untuk merangsang keluarnya air susu dari alveoli. Kerja oxytocin berlangsung 6-8 menit sehingga pemerahan perlu dilakukan secara cepat agar produksi susu optimal, pemerahan yang tidak optimal menyebabkan penurunan kualitas komponen susu karena terdapat residual milk terutama pada kadar lemak yang disebabkan oleh adanya sel somatik dalam jumlah banyak sehingga kadar lemak susu menurun. Sel somatik dalam susu merupakan sekresi epitel dan leokosit dalam susu. Pencucian ambing erat hubungannya dengan perangsangan dan aktifitas hormon oxytocin [7].

Penanganan pasca pemerahan yang dilakukan adalah melakukan celup puting (teat dipping) menggunakan antiseptik agar mikroba tidak masuk ke puting dan mencegah mastitis. Sesuai dengan pendapat [8] pencelupan puting dengan antiseptik mampu mengurangi skor mastitis dari angka o,6 menjadi o,15 dimana hal ini berarti menurunkan dan menekan jumlah sel somatik, sehingga kejadian mastitis dapat ditekan. [9] menyatakan bahwa salah satu kegiatan pasca pemerahan yang dapat menurunkan kejadian mastitis adalah teat dipping dan sanitasi alat/mesin perah. Setelah dilakukan pemerahan, susu dimasukkan ke dalam milkcan, kemudian susu dipasteurisari pada suhu $72^{\circ} \mathrm{C}$ selama 15 detik, selanjutnya susu dikemas dalam plastik kemudian dimasukkan ke dalam freezer untuk 
dibekukan sehingga menghambat pertumbuhan mikroba.

Pemeliharaan anak kambing dan kambing dara di PT. Boncah Utama yaitu anak yang lahir dibersihkan dan diberikan kolostrum, kemudian dipisahkan dari induknya. Pemberian kolostrum pada anak pada hari berikutnya dengan menggunakan botol dot bayi selama kurang lebih satu minggu.

Sub aspek pengeringan kambing laktasi yaitu $\mathbf{1 . 5}$ bulan menjelang kelahiran anak. Secara teoritis, sebaiknya pengeringan dilakukan 2 bulan sebelum beranak, hal ini bertujuan untuk persiapan sebelum melahirkan anak. Hal ini sesuai dengan pendapat [10] bahwa lama kering kandang yang baik berkisar antara 56-6o hari.

Sistim pencatatan usaha di PT. Boncah Utama tergolong kurang baik karena hanya memiliki rekording berupa produksi susu, biaya pakan dan biaya operasional lainnya. Namun rekording tentang pejantan, perkawinan, kelahiran, kesehatan belum dilakukan. Pencatatan usaha sangat penting agar usaha peternakan dapat mengevaluasi dan mengontrol perkembangannya.
Sub aspek manajemen kotoran atau limbah sudah baik. Feses dan urin tidak akan tercampur karena feses ditampung menggunakan jaring sedangkan urin akan turun dan mengalir ke saluran penampungan. Feses dikumpulkan dalam tempat penampung feses, kemudian dimasukkan ke dalam karung kapasitas $30 \mathrm{~kg}$ untuk dijual sebagai bahan baku pupuk kandang.

\subsection{Kandang dan Peralatan}

Kandang berfungsi sebagai pelindung dan untuk memudahkan pengelolaan. Disamping itu, kandang juga berfungsi sebagai tindakan preventif agar kambing tidak merusak tanaman dan fasilitas lain di lokasi peternakan, serta menghindari terkonsumsinya pakan berbahaya. Kandang juga mempermudah peternak melakukan kontrol terhadap kesehatan kambing. Berdasarkan evaluasi penerapan GDFP untuk aspek kandang dan peralatan (Tabel 7) skor rata-rata 3.83 dapat dikatakan bahwa performa peternakan termasuk kategori baik.

Tabel 7. Nilai Good Dairy Farming Practice kambing perah aspek kandang dan peralatan

\begin{tabular}{clcl}
\hline No & Faktor & Nilai GDFP & Kategori \\
\hline 1. & Tata letak kandang & 4 & Baik \\
2. & Konstruksi kandang & 4 & Baik \\
3. & Drainase kandang & 4 & Baik \\
4. & Tempat kotoran & 4 & Baik \\
5. & Peralatan kandang & 4 & Baik \\
6. & Peralatan susu & 3 & Cukup Baik \\
& Rata-rata & $\mathbf{3 . 8 3}$ & Baik \\
\hline
\end{tabular}

Bahan kandang terbuat dari kayu dengan bentuk kandang panggung dengan tinggi $\pm 1.5 \mathrm{~m}$ dari tanah. Lantai kandang dibuat dari bambu untuk memudahkan dalam pembersihan dan memudahkan kotoran jatuh ke lantai sehingga kondisi kandang tidak kotor dan ternak merasa nyaman.

Letak kandang terpisah dari rumah tinggal dan cukup jauh dari keramaian dengan jarak $100 \mathrm{~m}$ serta dekat dengan lahan pertanian, dan sinar matahari harus dapat menembus kandang [11]. Hasil pengamatan di lokasi penelitian, jarak rumah dan kandang berjauhan dengan rumah penduduk yaitu $\pm 75 \mathrm{~m}$. Tataletak bangunan diatur berdasarkan fungsinya dan jarak antar bangunan adalah $\pm 1.5 \mathrm{~m}$ untuk meminimalisir terjadinya perpindahan penyakit antar ternak. Kandang di lokasi penelitian terdiri dari kandang individu, kandang koloni, kandang pejantan, kandang cempe dan kandang isolasi. Luas kandang yaitu 1X1.5 untuk satu ekor kambing dewasa. Area yang terpisah disediakan peternak untuk mengisolasi ternak dan untuk perawatan ternak. Area perawatan dibuat dekat dengan kandang khusus untuk melahirkan dan untuk mengisolasi ternak yang sakit [12].

Peralatan kandang meliputi sapu lidi, ember pakan, gerobak, sekop, cangkul, sabit, dan chopper. Peralatan pemerahan susu meliputi ember perah, saringan, dan milkcan selalu dijaga kebersihannya dengan tindakan setelah peralatan digunakan segera dibersihkan menggunakan deterjen, selanjutnya dibilas dengan air bersih. Peralatan yang sudah bersih dikeringkan atau diletakkan terbalik. [13] menyatakan peralatan yang kotor akan mencemari susu sehingga mempercepat proses pembusukan, susu menjadi asam atau rusak, sehingga bakteri penyebab mastitis mudah menyebar.

\subsection{Kesehatan Ternak}

Berdasarkan evaluasi penerapan GDFP untuk aspek kesehatan ternak (Tabel 8) skor rata-rata untuk aspek kandang adalah 2.66 yang termasuk kategori cukup baik. 
Tabel 8. Nilai Good Dairy Farming Practice kambing perah pada aspek kesehatan

\begin{tabular}{clll}
\hline No & Faktor & Nilai GDFP & Kategori \\
\hline 1. & Pengetahuan penyakit & 3 & Cukup Baik \\
2. & Pencegahan penyakit & 2 & KurangBaik \\
3. & Pengobatan penyakit & 3 & Cukup Baik \\
& Rata-rata & $\mathbf{2 . 6 6}$ & Cukup Baik \\
\hline
\end{tabular}

Tingkat pengetahuan penyakit memperoleh nilai/skor 3 dengan kategori cukup baik. Penyakit yang pernah terjadi di lokasi penelitian adalah bloat/kembung, diare, scabies dan mastitis. Ternak yang sakit dilakukan pengobatan oleh petugas kandang. Pengobatan dan pencegahan terhadap penyakit perlu ditingkatkan. Kesadaran melakukan pencegahan dan pengobatan seperti vaksinasi, menjaga kebersihan kandang, memberikan obat cacing secara berkala dan pemberian vitamin belum dilakukan dengan baik.

Salah satu penyakit yang menyebabkan kerugian pada suatu usaha peternakan adalah mastitis. Mastitis merupakan peradangan pada ambing sehingga produksi susu berkurang. Mastitis telah banyak dilaporkan menyebabkan kerugian terutama berkurangnya produksi susu, menurunnya kualitas susu sampai pada gangguan fungsi kelenjar ambing dengan tidak berfungsinya ambing [14]; [15]; [16]; [17]. Upaya yang dapat dilakukan peternak untuk mengurangi kasus mastitis pada ternak kambing adalah selalu menjaga kebersihan dan hygiene ternak, hygienis pemerah maupun fasilitas kandang.

\section{Kesimpulan}

Aplikasi penerapan aspek teknis pemeliharaan menuju Good Dairy Farming Practice (GDFP) di peternakan kambing perah PT. Boncah Utama sudah tergolong baik. Nilai rata-rata GDFP tertinggi terdapat pada aspek kandang dan peralatan (kategori baik), sedangkan nilai rata-rata terendah pada aspek kesehatan ternak 2.66 (cukup baik). Beberapa aspek dalam GDFP yang belum diterapkan dengan baik yaitu sistim pemerahan dan kesehatan ternak. Kualitas susu kambing segar berdasarkan uji total plate count masih tinggi karena peternak belum sepenuhnya menerapkan GMiP (Good Milking Practice). Oleh karena itu disarankan untuk penerapan GMiP dengan baik agar agar kualitas susu khususnya jumlah koloni bakteri susu memenuhi standar yang sudah ditetapkan.

\section{Ucapan Terima Kasih}

Penulis mengucapkan terima kasih kepada Direktorat Riset dan Pengabdian kepada Masyarakat yang telah menyediakan dana untuk kegiatan penelitian ini melalui kontrak No. 034/SP2H/DRPM/2020 Tanggal 9 Maret 2020.

\section{Referensi}

[1] Food and Agriculture Organization [FAO]. 2011. Guide to Good Dairy Farming Practice. Internasional Dairy Federation Food and Agriculture Organization Of The United Nation, Rome.

[2] Mwambilwa K, Yambayamba E K, Simbaya J. 2013. Evaluation of the Reproductive Performance and Effectiveness of Artificial Insemination on Smallholder Dairy Farms in Zambia. Scholarly Journal. 3(10):391- 400. http://www.scholarly-journals.com/SJAS.

[3] Suherman, D. 2005. Imbangan Rumput Lapangan dan Konsentrat dalam Ransum terhadap Kualitas Produksi Susu Sapi Perah Holstein. Anim. Agric. J. 7(1): 14-20.

[4] Mathius, I. W., D. Yulistiani, E. Wina, B. Haryanto, A. Wilson dan A. Thalib. 2001. Pemanfaatan Energi untuk Meningkatkan Efisiensi Pakan pada Domba Induk. Jurnal Ilmu Ternak dan Veteriner. 6 (1): 7-13.

[5] Mardalena. 2008. Pengaruh Waktu Pemerahan dan Tingkat Laktasi Terhadap Kualitas Susu Sapi Perah Peranakan Fries Holstein. Jurnal Ilmiah Ilmu-Ilmu Peternakan. 9 (3): 107-111.

[6] Thai Agricultural Standard [TAS]. 20o8. Raw Goat Milk. National Bureau of Agricultural Commodity and Food Standards, Ministry of Agriculture and Cooperatives. ICS 67.100.01. Published in the Royal Gazette vol 125 Section 139 D, Thailand.

[7] Kentjonowaty, I., P. Trisunuwati, T. Susilawaty dan P. Surjowardojo. 2014. Evaluasi Profil Hormon Oxytocin, Kualitas dan Kuantitas Produksi Susu Sapi Perah pada Lama Mammae Hand Massage dari Berbagai Metode Pemerahan. Fakultas Peternakan, Universitas Brawijaya, Malang.

[8] Kurniawan, I., Sarwiyono dan P. Surjowardojo. 2013. Pengaruh Teat Dipping Menggunakan Dekok Daun Kersen (Muntingia calibura L.) terhadap Tingkat Kejadian Mastitis. Jurnal IlmuIlmu Peternakan 23: 27-31.

[9] Putri, P., Sudjatmogo and T. H. Suprayogi. 2015. The Effect of Durations Time of Dipping with Kaporit on Total Bacteria and $\mathrm{pH}$ of Dairy Cows Milk. Anim. Agric. J. 4 (1):132- 136.

[10] Djaja, W., R. H. Matondang dan Haryanto. 2009. Aspek Manajemen Usaha Sapi Perah. Pusat Penelitian dan Pengembangan Peternakan. Bogor 
[11] Direktorat Jenderal Peternakan [Ditjennak]. 2008. Petunjuk Teknis Pembibitan Ternak Rakyak (Village Breeding Centre atau VBC). Ditjen Peternakan, Jakarta

[12] Sabapara, G. P., V. B Kharadi, L. M Sorthiya and D. C Patel. 2014. Housing, Health Care and Milking Management Practices Followed by Goat Owners in Navsari District of Gujarat. Sch. J Agric Vet Sci. 1(4): 164-167

[13] Handayani, K. S dan Purwanti M. 2010. Kesehatan Ambing dan Higiene Pemerahan di Peternakan Sapi Perah Desa Pasir Buncir Kecamatan Caringin. Jurnal Penyuluhan Pertanian $5(1): 47-54$

[14] Andriani. 2010. Pengaruh Suplementasi Mineral Seng Terhadap Kualitas Susu Kambing Peranakan Etawah. Jurnal Penelitian Universitas Jambi Seri Humaniora, Vol 15 No. 1 Hal : o1-o8.

[15] Bourabah, A., A. Ayad, L. Boukraa, S. Hammoudi and H. Benbarek. 2013. Prevalence and Etiology of Subclinical Mastitis in Goats of the Tiaret Region, Algeria. Global Veterinaria 11 (5): 604608, DOI: 10.5829/ idosi. gv. 2013.11.5.8112.

[16] Koop, G., T. V. Werven, H. J. Schuiling and M. Nielen. 2010. The Effect of Subclinical Mastitis on Milk Yield in Dairy Goats. J Dairy Sci. 93(12) : 5809-5817 DOI: http://dx.doi.org/10.3168/jds.2010-3544.

[17] McDougall, S., K. Supré, S. De Vliegher, F. Haesebrouck, H. Hussein, L. Clausen and C. Prosser. 2010. Diagnosis and Treatment of Subclinical Mastitis in Early Lactation in Dairy Goats. J Dairy Sci. 93 (10): 4710-21. doi: 10.3168/jds.2010-3324. 